WMJ (Warmadewa Medical Journal), Vol. 1 No. 2 November 2016, Hal. 58-65

\title{
Efek Pemberian Virgin Coconut Oil (Cocos nucifera) Terhadap Dislipidemia pada Tikus Putih (Rattus norvegicus) Jantan Galur Wistar yang Diberi Diet Tinggi Kolesterol
}

\author{
Augus Venty ${ }^{1}$, I Gusti Made Aman², Wimpie Pangkahila ${ }^{3}$ \\ ${ }^{1}$ Program Pascasarjana Ilmu Biomedik Anti-Aging Medicine, ${ }^{2}$ Departemen Farmakologi, ${ }^{3}$ Departemen \\ Andrologi dan Seksologi, Fakultas Kedokteran, Universitas Udayana, Jln. PB Sudirman, Denpasar, Bali, \\ Indonesia. ${ }^{1}$ E-mail:drventy@yahoo.com
}

\begin{abstract}
Abstrak
Dislipidemia adalah kelainan metabolisme lipid yang ditandai peningkatan kolesterol total, kolesterol LDL, trigliserida diatas nilai normal serta penurunan kolesterol HDL di dalam darah. Virgin coconut oil (VCO) mengandung $92 \%$ lemak jenuh sehingga dikaitkan dengan peningkatan resiko penyakit kardiovaskular. Tidak semua asam lemak jenuh buruk bagi kesehatan. VCO terdiri dari medium chain triglycerides (MCT) dan komponen polifenol bekerja secara sinergis dalam mencegah dislipidemia. Penelitian ini bertujuan untuk mengetahui kegunaan VCO sebagai alternatif untuk mencegah dislipidemia pada tikus putih jantan galur wistar yang diberi diet tinggi kolesterol. Penelitian ini adalah penelitian eksperimental murni dengan randomized post-test only control group design menggunakan 36 ekor tikus putih jantan. Semua sampel diberikan diet tinggi kolesterol, lalu dibagi menjadi 2 kelompok secara random yaitu kelompok kontrol yang diberikan plasebo berupa akuades sebanyak $0,8 \mathrm{ml} /$ hari dan kelompok perlakuan yang diberikan VCO sebanyak $0,8 \mathrm{ml} / 200$ gram berat badan/ hari selama 28 hari. Hasil penelitian ini menunjukkan bahwa rerata kolesterol total kelompok perlakuan lebih rendah dari kelompok kontrol $(113,49 \pm 4,31 \mathrm{mg} / \mathrm{dl}$ vs $222,61 \pm 6,41$ $\mathrm{mg} / \mathrm{dl})(\mathrm{p}<0,05)$. Rerata trigliserida kelompok perlakuan lebih rendah dari kelompok kontrol $(91,46 \pm 5,56 \mathrm{mg} /$ dl vs $153,51 \pm 5,40 \mathrm{mg} / \mathrm{dl})(\mathrm{p}<0,05)$. Rerata kolesterol LDL kelompok perlakuan lebih rendah dari kelompok kontrol $(37,94 \pm 3,32 \mathrm{mg} / \mathrm{dl}$ vs $71,25 \pm 2,76 \mathrm{mg} / \mathrm{dl})(\mathrm{p}<0,05)$. Rerata kolesterol HDL kolesterol total kelompok perlakuan lebih tinggi dari kelompok kontrol $(41,62 \pm 1,58 \mathrm{mg} / \mathrm{dl}$ vs $25,02 \pm 2,59 \mathrm{mg} / \mathrm{dl})(\mathrm{p}<0,05)$. Penelitian ini menyimpulkan bahwa virgin coconut oil mencegah dislipidemia pada tikus jantan galur wistar yang diberi diet tinggi kolesterol.
\end{abstract}

Kata Kunci: virgin coconut oil, profil lipid, dyslipidemia.

\begin{abstract}
[The Effect of Virgin Coconut Oil (Cocos nucifera) to Dyslipidemia in Male Wistar Rats (Rattus norvegicus) Fed with High Cholesterol Diet].

Dyslipidemia is a lipid metabolism disorder characterized by high total cholesterol level, high LDL cholesterol level, high tryglyceride level and low HDL cholesterol level. Virgin coconut oil (VCO) contains 92\% saturated fat that is associated with an increased risk of cardiovascular disease. Not all saturated fatty acids are bad for health. VCO consist of medium chain triglycerides (MCTs) and polyphenol components that work synergistically in preventing dyslipidemia. This research was aimed to determine the usefulness of VCO as an alternative to prevent dyslipidemia in male wistar rats fed with high cholesterol diet. This study was a true experimental research with randomized post-test only control group design using 36 male rats. All samples were given a high cholesterol diet and were divided into 2 groups randomly: a control group were given a placebo (distilled water) $0,8 \mathrm{ml} /$ day and a treatment group were given VCO 0,8 $\mathrm{ml} / 200 \mathrm{gram}$ weight/ day for 28 days. The results showed that the treatment group had a significantly lower total cholesterol levels compared to the control group $(113,49 \pm 4,31 \mathrm{mg} / \mathrm{dl}$ vs 222,61 $\pm 6,41 \mathrm{mg} / \mathrm{dl})(p<0,05)$. The treatment group had a significantly lower triglycerides levels compared to the control group $(91,46 \pm 5,56 \mathrm{mg} / \mathrm{dl} \mathrm{vs} 153,51 \pm 5,40 \mathrm{mg} /$ dl) $(p<0,05)$. The treatment group had a significantly lower LDL cholesterol levels compared to the control group $(37,94 \pm 3,32 \mathrm{mg} / \mathrm{dl} v \mathrm{~s} 71,25 \pm 2,76 \mathrm{mg} / \mathrm{dl})(p<0,05)$. The treatment group had a significantly higher $H D L$ cholesterol levels compared to the control group $(41,62 \pm 1,58 \mathrm{mg} / \mathrm{dl} v \mathrm{vs} 25,02 \pm 2,59 \mathrm{mg} / \mathrm{dl})(p<0,05)$. This research concluded that virgin coconut oil was proved in preventing dyslipidemia in male wistar rats fed with high cholesterol diet.
\end{abstract}

Keywords: virgin coconut oil, lipid profile, dyslipidemia. 


\section{PENDAHULUAN}

Dislipidemia merupakan salah satu masalah kesehatan yang terjadi di masyarakat, baik di Indonesia maupun di dunia dan angka kejadiannya terus meningkat. Dislipidemia mempercepat proses penuaan karena berdampak pada terjadinya arteriosklerosis dan menyebabkan penyakit jantung koroner. Dislipidemia adalah kelainan metabolisme lipid yang ditandai peningkatan kolesterol total, kolesterol LDL, trigliserida serta penurunan kolesterol HDL di dalam darah.

Virgin coconut oil mengandung 92\% lemak jenuh sehingga dianggap dapat meningkatkan risiko aterosklerosis dan penyakit jantung koroner. ${ }^{[2]}$ Tidak semua asam lemak jenuh/ saturated fatty acid (SFA) buruk bagi kesehatan. Lemak jenuh tidak hanya satu jenis saja, melainkan terdiri dari 3 sub grup, yaitu: asam lemak rantai pendek/ short chain fatty acid (SCFA) (C4-C6), asam lemak rantai sedang/ medium chain fatty acid (MCFA) (C8-C12), dan asam lemak rantai panjang/ long chain fatty acid (LCFA) ( $\geq \mathrm{C} 14){ }^{[2,3]}$

Perbedaan panjang rantai karbon dalam asam lemak yang terkandung dalam komposisi minyak menentukan absorbsi, transportasi, dan metabolismenya ${ }^{[4,5]}$. Lemak jenuh pada minyak kelapa sangat berbeda dengan lemak jenuh yang berasal dari hewan, karena lemak jenuh pada minyak kelapa adalah jenis medium chain fatty acids atau asam lemak rantai sedang [6].

Virgin coconut oil atau VCO adalah minyak kelapa murni yang berasal dari buah kelapa segar, yang diproses secara alamiah tanpa menggunakan zat kimia atau bahan sintetik lainnya, tanpa melalui proses refining, bleaching, dan deodorizing ( $R B D$ process $)^{[7]}$. Pada virgin coconut oil terkandung medium chain triglycerides (MCT) dan komponen antioksidan. VCO merupakan minyak yang komposisinya sebanyak $70 \%$ adalah asam lemak rantai sedang atau $\mathrm{MCT}^{[8]}$. VCO meregulasi oksidasi asam lemak via PPAR- $\alpha$ dependent pathways $^{[9]}$. Kandungan antioksidan pada VCO didominasi oleh gugus polifenol ${ }^{[10]}$. Komponen polifenol diketahui dapat mencegah oksidasi LDL pada tikus ${ }^{[11]}$.

Penelitian terdahulu mengenai efek VCO pada tikus galur wistar yang dibuat menjadi diabetes, lalu diberi diet VCO 10\% selama 3 minggu menunjukkan adanya perbaikan profil lipid yang signifikan pada kelompok perlakuan ${ }^{[12]}$. Penelitian lainnya pada tikus spraque-dawley yang diberi alkohol 30\%, lalu diberi VCO dengan dosis $6,67 \mathrm{ml} / \mathrm{kg}$ berat badan/ hari selama 4 minggu juga didapatkan hasil VCO mampu mempertahankan nilai profil lipid mendekati normal ${ }^{[13]}$.

Lemak jenuh kerap dianggap sebagai penyebab utama penyakit kardiovaskular selama beberapa dekade ${ }^{[14]}$. Sebuah studi kohort prospektif terhadap manusia dalam rentang waktu 5 sampai 23 tahun menunjukkan tidak ada bukti signifikan bahwa diet lemak jenuh berkaitan dengan peningkatan resiko penyakit jantung koroner maupun stroke ${ }^{[15]}$.

Virgin coconut oil yang beredar di pasaran kualitasnya berbeda-beda ${ }^{[16]}$. Pada penelitian ini digunakan VCO yang memenuhi standar mutu dari Asian and Pacific Coconut Community. Tujuan penelitian ini adalah untuk membuktikan bahwa pemberian VCO dapat mencegah dislipidemia pada tikus putih jantan galur wistar.

\section{METODE}

Virgin coconut oil dibuat dengan metode cold-pressed, dibeli dari Bali Pure Home Industry, Desa Tejakula, Sembiran, Bali Utara. Diet tinggi kolesterol adalah bahan makanan yang distandarisasi untuk memenuhi syarat tinggi kolesterol dengan komposisi: kuning telur 5\%, lemak babi $10 \%$, minyak goreng $1 \%$, dan makanan standar sampai $100 \%$, yang didapat dari Laboratorium Farmakologi Universitas Udayana, Denpasar, Bali.

Hewan coba berupa tikus putih (Rattus norvegicus) jantan galur wistar berusia 3-4 bulan, sehat, berat badan 160180 gram. Penelitian ini sudah mendapat 
kelaikan etik dari Fakultas Kedokteran Hewan Universitas Udayana dengan nomor surat: 262/KE-PH-Lit-2/VIII/2016.

Penelitian ini merupakan penelitian eksperimental dengan post-test only control group design, menggunakan 36 ekor tikus putih (Rattus norvegicus) jantan galur wistar yang sehat, umur 3-4 bulan, berat badan 160-180 gram. Dari populasi tikus jantan diadakan pemilihan sampel berdasarkan kriteria inklusi. Dari jumlah sampel yang telah memenuhi syarat, diambil secara random. Dari sampel yang telah dipilih kemudian dibagi menjadi 2 kelompok yaitu kelompok kontrol yang diberikan diet tinggi kolesterol serta akuades $0,8 \mathrm{ml} /$ hari dan kelompok perlakuan yang diberikan diet tinggi kolesterol serta VCO $0,8 \mathrm{ml} / 200$ gram berat badan/ hari selama 28 hari. Tikus terlebih dahulu diaklimatisasi selama 1 minggu, lalu ditimbang berat badannya, kemudian diberikan perlakuan selama 28 hari. Pakan yang diberikan sebanyak 15 gram/ hari. Air minum diberikan secara ad libitum. Sisa pakan ditimbang keesokan harinya selama 28 hari. Pada hari ke 29, kedua kelompok tikus ditimbang berat badannya, kemudian dipuasakan selama 18 jam untuk selanjutnya diambil sampel darah untuk diperiksa kadar kolesterol total, trigliserida, LDL dan HDL. Pemeriksaan kadar kolesterol total, LDL dan HDL dengan menggunakan metode CHOP-PAP (Bochringer-Mennheim GmBp). Kadar trigliserida diukur dengan menggunakan metode GOP-PAP (Bochringer-Mennheim GmBp). Pemeriksaan profil lipid dilakukan di Laboratorium Gizi dan Pangan Universitas Gajah Mada. Berat badan tikus dan sisa pakan tikus ditimbang dengan timbangan khusus merk Shunle yang tersedia di Laboratory Animal Unit Universitas Udayana.

Data dianalisis dengan menggunakan SPSS. Uji normalitas dengan menggunakan uji Saphiro-Wilk. Uji komparabilitas dengan menggunakan uji $t$ tidak berpasangan.

\section{HASIL}

Berikut ini adalah tabel hasil kolesterol total, trigliserida, LDL dan HDL, serta pakan yang dimakan dan kenaikan berat badan setelah diberi perlakuan:

Tabel 1 Perbedaan Rerata Kolesterol Total, Trigliserida, Kolesterol LDL, Kolesterol HDL, Pakan yang Dimakan dan Kenaikan Berat Badan antar Kelompok Sesudah Diberikan Perlakuan

\begin{tabular}{llll}
\hline \multicolumn{1}{c}{ Variabel } & \multicolumn{1}{c}{$\begin{array}{c}\text { Kelompok Kontrol } \\
(\text { rerata } \pm \text { SB) } \\
\mathbf{n = 1 8}\end{array}$} & $\begin{array}{c}\text { Kelompok Perlakuan } \\
(\text { rerata } \pm \text { SB }) \\
\mathbf{n = 1 8}\end{array}$ & p \\
\hline Kolesterol total (mg/dl) & $222,61 \pm 6,41$ & $113,49 \pm 4,31$ & 0,000 \\
Trigliserida (mg/dl) & $153,51 \pm 5,40$ & $91,46 \pm 5,56$ & 0,000 \\
Kolesterol LDL (mg/dl) & $71,25 \pm 2,76$ & $37,94 \pm 3,32$ & 0,000 \\
Kolesterol HDL (mg/dl) & $25,02 \pm 2,59$ & $41,62 \pm 1,58$ & 0,000 \\
Pakan yang dimakan (gram) & $12 \pm 0,19$ & $11,33 \pm 0,43$ & 0,000 \\
Kenaikan berat badan (gram) & $21,94 \pm 0,66$ & $18,33 \pm 0,68$ & 0,000 \\
\hline
\end{tabular}

Keterangan: $\mathrm{SB}=$ Simpang Baku 


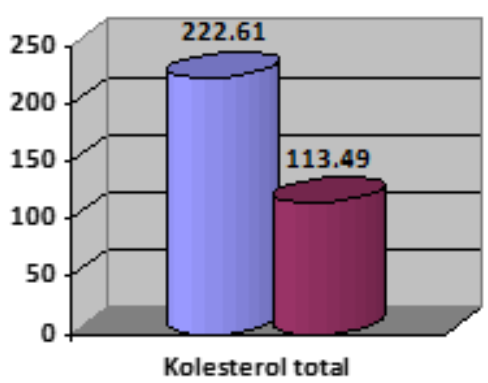

$\square$ Kontrol

口 Perlakuan

Grafik 1 Efek Pemberian VCO terhadap Kadar Kolesterol Total.

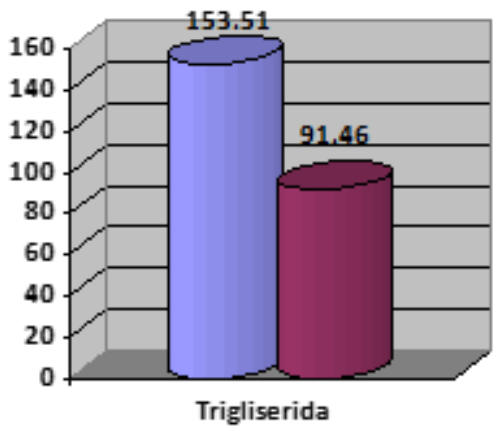

$\square$ Kontrol

$\square$ Perlakuan

Grafik 2 Efek Pemberian VCO terhadap Kadar Trigliserida.

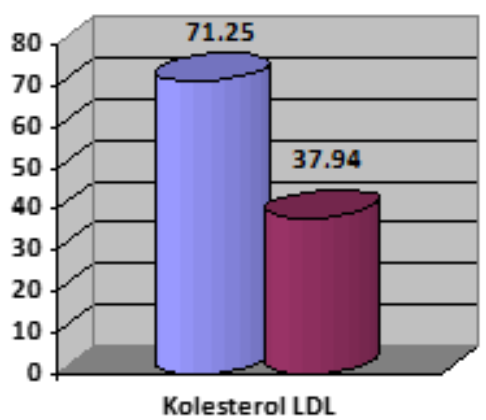

a Kontrol

口 Perlakuan

Grafik 3 Efek Pemberian VCO terhadap Kadar Kolesterol LDL

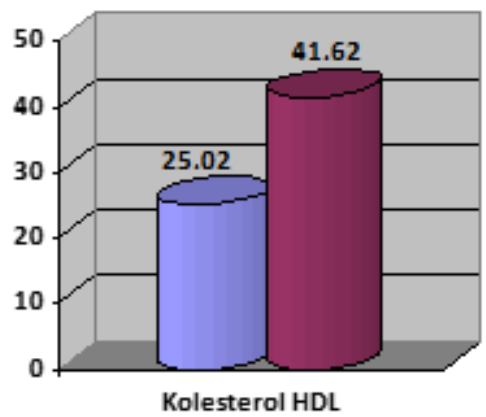

a Kontrol

a Perlakuan

Grafik 4 Efek Pemberian VCO terhadap Kadar Kolesterol HDL

\section{PEMBAHASAN}

Hasil penelitian ini menunjukkan bahwa rerata kolesterol total kelompok perlakuan lebih rendah dari kelompok kontrol $(113,49 \pm 4,31 \mathrm{mg} / \mathrm{dl}$ vs $222,61 \pm 6,41$ $\mathrm{mg} / \mathrm{dl}) \quad(\mathrm{p}<0,05) . \quad$ Rerata trigliserida kelompok perlakuan lebih rendah dari kelompok kontrol $(91,46 \pm 5,56 \mathrm{mg} / \mathrm{dl}$ vs $153,51 \pm 5,40 \quad \mathrm{mg} / \mathrm{dl}) \quad(\mathrm{p}<0,05) . \quad$ Rerata kolesterol LDL kelompok perlakuan lebih rendah dari kelompok kontrol $(37,94 \pm 3,32$ $\mathrm{mg} / \mathrm{dl}$ vs $71,25 \pm 2,76 \mathrm{mg} / \mathrm{dl}) \quad(\mathrm{p}<0,05)$. Rerata kolesterol HDL kolesterol total kelompok perlakuan lebih tinggi dari kelompok kontrol $(41,62 \pm 1,58 \mathrm{mg} / \mathrm{dl}$ vs $25,02 \pm 2,59 \mathrm{mg} / \mathrm{dl})(\mathrm{p}<0,05)$.

Hasil penelitian ini didukung oleh hasil-hasil penelitian sebelumnya. Penelitian pemberian diet VCO 10\% selama 8 minggu pada tikus wistar diabetes didapatkan hasil VCO dapat memperbaiki profil lipid ${ }^{[12]}$. Penelitian pemberian VCO dengan dosis $6,67 \mathrm{ml} / \mathrm{kg}$ berat badan/ hari selama 4 minggu pada tikus spraque-dawley yang diberi alkohol 30\% juga didapatkan hasil VCO mampu mempertahankan nilai profil lipid mendekati batas normal ${ }^{[13]}$. Hasil yang didapatkan dari penelitian tersebut sejalan dengan hasil pada penelitian ini karena setelah perlakuan selama 28 hari pada tikus wistar jantan yang diberi diet tinggi kolesterol dan VCO 0,8 ml/ 200 gram berat badan tikus didapatkan perbedaan bermakna dari profil lipid, dimana terjadi penurunan kolesterol total, trigliserida, kolesterol LDL dan peningkatan kolesterol LDL $(p<0,05)$. Jadi hasil pada penelitian ini membuktikan bahwa asupan virgin coconut oil bermanfaat dalam mencegah timbulnya dislipidemia.

Pemberian VCO mencegah dislipidemia melalui beberapa mekanisme yaitu menurunkan lipogenesis dari hepar, meningkatkan $\beta$-oksidasi di mitokondria 
dan peroksisom dan meningkatkan reverse cholesterol transport. VCO yang terdiri dari MCT dan komponen polifenol bekerja secara sinergis dalam mencegah dislipidemia. MCT adalah ligan natural PPAR- $\alpha$. Suplementasi VCO akan meningkatkan ekspresi mRNA dari PPAR$\alpha$. Aktivasi PPAR- $\alpha$ akan upregulating gengen yang berkaitan dengan oksidasi asam lemak seperti Carnitine Palmitoyl Transferase (CPT I) dan acyl CoA oxidase sehingga dapat mensupresi lipidemia postprandial dan akumulasi lipid. VCO meregulasi oksidasi asam lemak via PPAR$\alpha$-dependent pathways ${ }^{[9]}$.

Aktivasi PPAR- $\alpha$ juga akan meningkatkan aktivitas enzim lipoprotein lipase di hepar dan otot rangka, klirens trigliserida akan meningkat. Aktivasi PPAR - $\alpha$ juga akan menginduksi ekspresi ABCA1 dan SR-B1. Apo A-I dan apo A-II yang berkaitan dengan HDL merupakan target langsung PPAR- $\alpha$. Apo A-I akan mengaktifkan lecithin cholesterol acyltransferase (LCAT), apo A-II akan meningkatkan aktivitas hepatic lipase $e^{[17]}$. Peningkatan enzim lipoprotein lipase, LCAT dan HDL berperan penting dalam reverse cholesterol transport ${ }^{[17,18]}$.

Diet mengandung MCT dapat meningkatkan kadar adiponektin pada serum dan jaringan adiposit ${ }^{[19,20]}$. Peningkatan kadar adiponektin akan menurunkan akumulasi lemak, memperbaiki sensitivitas insulin dan meningkatkan oksidasi asam lemak pada otot. Adiponektin akan mengaktivasi AMPactivated protein kinase (AMPK) yang dimediasi melalui AdipoR1 dan juga adiponektin akan meningkatkan ekspresi gen-gen dari PPAR- $\alpha$ via AdipoR2, sehingga meningkatkan aktivitas enzim seperti acyl CoA oxidase yang terlibat dalam oksidasi asam lemak dan UCP2 yang terlibat dalam pembentukan energi ${ }^{[21]}$.

AMPK saat diaktivasi akan mengalihkan sel dari proses biosintesis asam lemak dan kolesterol yang memerlukan ATP ke proses oksidasi asam lemak yang menghasilkan $\mathrm{ATP}^{[22]}$. AMPK akan menon-aktifkan acetyl-CoA carboxylase sehingga konsentrasi malonylCoA menurun. Malonyl-CoA merupakan inhibitor enzim CPT I. Penurunan malonyl CoA akan menyebabkan peningkatan oksidasi asam lemak di mitokondria ${ }^{[23]}$. AMPK juga akan menginhibisi kerja enzim HMG-KoA reduktase ${ }^{[24]}$.

Medium chain triglycerides (MCT) memiliki efek menekan lipogenesis. VCO, yang direfleksikan dari penurunan aktivitas enzim HMG-CoA reductase, glucose-6phosphate dehydrogenase, isocitrate dehydrogenase dan malic pada tikus yang diberi $\mathrm{VCO}^{[18]}$. Enzim glucose-6-phosphate dehydrogenase, isocitrate dehydrogenase dan malic merupakan enzim-enzim penghasil NADPH. NADPH sangat penting dan harus ada untuk mensintesis asam lemak maupun kolesterol ${ }^{[25]}$.

Enzim yang terlibat dalam biosintesis asam lemak de novo yaitu fatty acid synthase (FAS) dan acetyl CoA carboxylase, aktivitasnya menurun pada tikus yang diberi VCO. Kandungan polifenol pada VCO dapat mengakibatkan down-regulation ekspresi mRNA dari enzim FAS di hepar dan faktor transkripsinya sterol regulatory element-binding protein $1 c$ atau SREBP- $1 \mathrm{c}^{[18]}$.

VCO meningkatkan sintesis asam empedu di hati dan meningkatkan ekskresi asam empedu melalui feses. Kandungan fitosterol dalam VCO juga membantu menghambat absorbsi lipid pada usus ${ }^{[26]}$.

Rerata pakan yang dimakan kelompok kontrol adalah $12 \pm 0,19$ gram dan rerata kelompok perlakuan adalah 11,33 $\pm 0,43$ 
gram. Analisis kemaknaan dengan uji $\mathrm{t}$ independen menunjukkan bahwa nilai $\mathrm{p}=0,000$. Hal ini berarti bahwa kedua kelompok sesudah diberikan perlakuan, memiliki rerata pakan yang dimakan yang berbeda bermakna $(\mathrm{p}<0,05)$.

Pada kelompok perlakuan didapatkan asupan makanan yang lebih rendah daripada kelompok kontrol. Hal ini disebabkan kandungan medium chain triglyceride (MCT) dalam VCO dapat meningkatkan kadar adiponektin ${ }^{[19,20]}$. Adiponektin dapat menghambat nafsu makan sehingga konsumsi makanan berkurang ${ }^{[27]}$.

Rerata kenaikan berat badan kelompok kontrol adalah 21,94 $\pm 0,66$ gram dan rerata kelompok perlakuan adalah $18,33 \pm 0,68$ gram. Analisis kemaknaan dengan uji $\mathrm{t}$ berpasangan menunjukkan bahwa nilai $\mathrm{p}=0,000$. Hal ini berarti bahwa kedua kelompok sesudah diberikan perlakuan, memiliki kenaikan berat badan yang berbeda bermakna $(p<0,05)$.

Diet tinggi kolesterol dalam penelitian ini mengandung 371,47 kkal/ 100 gram. Pada kelompok kontrol yang diberi diet tinggi kolesterol dan akuades, rerata pakan yang dimakan adalah 12 gram/ hari $(371,47$ $\mathrm{kkal} / 100$ gram), jadi mengandung 44,57 kkal. Pada kelompok perlakuan yang diberi diet tinggi kolesterol dan VCO, rerata pakan yang dimakan adalah 11,33 gram/ hari (371,47 kkal/ 100 gram), jadi mengandung 42,08 kkal. Rerata berat badan tikus di awal penelitian adalah 166,39 gram, sehingga rerata VCO yang diberikan $0,66 \mathrm{ml} /$ hari atau setara $0,62 \mathrm{gram} /$ hari $(8,3 \mathrm{kkal} / \mathrm{gram})$, jadi mengandung 5,15 kkal. Total intake kalori kelompok perlakuan yaitu 47,23 kkal.

Kenaikan berat badan kelompok perlakuan lebih sedikit dibandingkan kelompok kontrol walaupun intake kalori pada kelompok perlakuan lebih tinggi daripada kelompok kontrol. Temuan ini menunjukkan bahwa VCO dapat meningkatkan metabolisme. Hal ini juga dapat disebabkan adanya peningkatan thermogenesis setelah konsumsi $\mathrm{MCT}^{[28]}$. Suplementasi VCO dapat menstimulasi ekspresi UCP1 atau yang dikenal dengan thermogenin, sehingga menimbulkan efek thermogenesis ${ }^{[29]}$. MCT juga meningkatkan energy expenditure sebagai efek sekunder dari peningkatan $\beta$-oksidasi asam lemak sehingga dapat menurunkan massa lemak tubuh $^{[26,28,29]}$. MCT lebih bersifat sebagai sumber energi instan daripada sebagai cadangan lemak ${ }^{[4]}$.

\section{SIMPULAN}

Dari penelitian ini dapat disimpulkan bahwa virgin coconut oil dapat mencegah peningkatan kadar kolesterol total, trigliserida, LDL dan mencegah penurunan HDL pada tikus putih jantan galur wistar yang diberi diet tinggi kolesterol. Perlu dilakukan penelitian lebih lanjut untuk mengetahui mekanisme VCO dalam meningkatkan metabolisme.

\section{UCAPAN TERIMA KASIH}

Ucapan terima kasih kepada bagian Laboratory Animal Unit, Departemen Farmakologi Fakultas Kedokteran Universitas Udayana yang membantu pelaksanaan penelitian.

\section{DAFTAR PUSTAKA}

1. Adam, J.M.F. Dislipidemia. In: Sudoyo, A. W., Setiyohadi, B., Alwi, I., Simadibrata, M., Setiati, S., editors. Buku Ajar Ilmu Penyakit Dalam. Edisi IV Jilid III. Jakarta: Pusat Penerbitan Departemen Ilmu Penyakit Dalam Fakultas Kedokteran Universitas Indonesia; 2006. p.1926-1929.

2. Dayrit, C. S. (2003). Coconut Oil: Atherogenic or Not? Philippine Journal of Cardiology Volume 31 Number 3: 97 104. 
3. Kabara, J. J [homepage on the internet]. Health Oils from the Tree of Life; 2005 [updated 2005; cited 2016 April 1]. Available from: www.biococo.com.my/ health_oil_from_the_tree_of_life_kabar a.pdf.

4. Takeuchi, H., Sekine, S., Kojima, K., Aoyama, T. (2008). The Application of Medium-Chain Fatty Acids: Edible Oil with a Suppressing Effect on Body Fat Accumulation. Asia Pacific Journal of Clinical Nutrition 2008; 17 (S1): 320323.

5. Roy, H. J. (2013). Health Effects of Coconut Oil. Pennington Biomedical Research Center, Pub No. 94.

6. Uragoda, C. G., Goonaratna, C., DPhil, J. S. (2006). Coconut Fats. The Ceylon Medical Journal Volume 51, No 2.

7. Marina, A. M., Che Man, Y. B., Amin, I. (2009). Virgin Coconut Oil: Emerging Functional Food Oil. Trends in Food Science and Technology 20 (2009) 481487.

8. Liau, K. M., Lee, Y. Y., Chen, C. K., Rasool, A. H. (2011). An Open-Label Pilot Study to Assess the Efficacy and Safety of Virgin Coconut Oil in Reducing Visceral Adiposity. ISRN Pharmacology 2011: 949686.

9. Arunima, S. \& Rajamohan, T. (2014). Influence of Virgin Coconut Oil Enriched Diet on the Transcriptional Regulation of Fatty Acid Synthesis and Oxidation in Rats - A Comparative Study. Br J Nutr. 2014 May 28; 111(10): 1782-90.

10. Abujazia, M. A., Muhammad, N., Shuid, A. N., Soelaiman, I. N. (2012). The Effects of Virgin Coconut Oil on Bone Oxidative Status in Ovariectomised Rat. Evidence-Based Complementary and Alternative Medicine Volume 2012, Article 525079.

11. Nurul-Iman, B. S., Kamisah, Y., Jaarin, K., Qodriyah, M. S. (2013). Virgin Coconut Oil Prevents Blood Pressure Elevation and Improves Endothelial Function in Rats Fed with Repeatedly Heated Palm Oil. Evidence-Based
Complementary and Alternative Medicine 2013: 629329.

12. Akinnuga, A. M., Jeje, S. O., Bamidele, O., Sunday, V. E. (2014). Dietary Consumption of Virgin Coconut Oil Ameliorates Lipid Profiles in Diabetic Rats. Hindawi Publishing Corporation Physiology Journal Volume 2014.

13. Dosumu, O. O., Akinola, O. B., Akang, E. N. (2012). Alcohol-Induced Testicular Oxidative Stress and Cholesterol Homeostasis in Rats - The Therapeutic Potential of Virgin Coconut Oil. Middle East Fertility Society Journal (2012) 17, 122-128.

14. DiNicolantonio, J. J., Lucan, S. C., O'Keefe, J. H. (2015). The Evidence for Saturated Fat dan for Sugar Related to Coronary Heart Disease. Progress in Cardiovascular Diseases.

15. Siri-Tarino, P. W., Sun, Q., Hu, F. B., Krauss, R. M. (2010). Meta-Analysis of Prospective cohort Studies Evaluating the Association of Saturated Fat with Cardiovascular disease. $\mathrm{Am} \mathrm{J}$ Clin Nutr 2010;91:535-46.

16. Novarianto, H. \& Tulalo, M. (2007). Kandungan Asam Laurat pada Berbagai Varietas Kelapa Sebagai Bahan Baku VCO. Jurnal Littri Vol.12 No.1, 28-33.

17. The Medical Biochemistry [homepage on the internet]. Peroxisome Proliferator -Activated Receptors, PPARs; 2015. [updated 2015 May; cited 2016 March 28]. Available from: http://themedical biochemistrypage.org/ppar.php.

18. Arunima, S. \& Rajamohan, T. (2012). Virgin Coconut Oil Improves Hepatic Lipid Metabolism in Rats- Compared with Copra Oil, Olive Oil and Sunflower Oil. Indian J Exp Biol. 2012 Nov; 50 (11):802-9.

19. Takeuchi, H., Noguchi, O., Sekine, S., Kobayashi, A., Aoyama, T. (2006). Lower Weight Gain and Higher Expression and Blood Levels of Adiponectin in Rats Fed Medium-Chain TAG Compared with Long-Chain TAG. Lipids 2006;41:207-12.

20. Nagao, K. \& Yanagita, T. (2010). Medium-Chain Fatty Acids: Functional 
Lipids for the Prevention and Treatment of the Metabolic Syndrome. Pharmacological Research 61 (2010) 208-212.

21. Okada-Iwabu, M., Iwabu, M., Ueki, K., Yamauchi, T., Kadowaki, T. (2015). Perspective of Small-Molecule AdipoR Agonist for Type 2 Diabetes and Short Life in Obesity. Diabetes Metab J. 2015 Oct;39(5):363-372.

22. The Medical Biochemistry [homepage on the internet]. AMPK: Master Metabolic Regulator; 2016. [updated 2016 August; cited 2016 March 28]. Available from: http://themedical biochemistry page.org/ppar.php.

23. Ferre, P. (2004). The Biology of Peroxisome Proliferator Activated Receptors Relationship with Lipid Metabolism and Insulin Sensitivity. Diabetes Vol.53 (suppl 1): S43-S50.

24. Hardie, D. G. (2007). AMP-activated/ SNF1 Protein Kinase: Conserved Guardians of Cellular Energy. Nature Reviews Molecular Cell Biology 8, 774785. doi:10.1038/nrm2249.

25. Botham, K. M. \& Mayes P. A. Cholesterol Synthesis, Transport, and Excretion. In: Murray, R. K., Bender,
D. A., Botham, K. M., Kennelly, P. J., Rodwell, V. W., Weil, P. A., editors. Harper's Illustrated Biochemistry. 28 th edition. New York: Mc Graw's Hill; 2009. p. 224-232.

26. Jaarin, K., Norliana, M., Kamisah, Y., Nursyafiza, M., Qosriyah, M. S. (2014). Potential Role of Virgin Coconut Oil in Reducing Cardiovascular Risk Factors. Exp Clin Cardiol Vol 20 issue 8 pages 3399-3410.

27. Austin, J. \& Marks, D. (2008). Hormonal Regulators of Appetite. International Journal of Pediatric Endocrinology, Volume 2009, Article ID 141753.

28. Marten, B., Pfeuffer, M., Schrezenmeir, J. (2006). Medium-Chain Triglycerides. International Dairy Journal 16 (2016) 1374-1382.

29. Dayrit, F. M. (2014). Lauric Acid is a Medium-Chain Fatty Acid, Coconut Oil is a Medium-Chain Triglyceride. Philippine Journal of Science 143(2): 157-166. 